\title{
On the absence of genetic differentiation between morphotypes of the ballan wrasse Labrus bergylta (Labridae)
}

F. Almada 1,*

Phone +351218811700

Email frederico.almada@gmail.com

L. Casas 2

S. M. Francisco 1

D. Villegas-Ríos 3

F. Saborido-Rey 4

X. Irigoien 2

J. I. Robalo 1

1 MARE - Marine and Environmental Sciences Centre, ISPA Instituto Universitário, Rua Jardim do Tabaco 34, 1149-041 Lisbon, Portugal

2 Red Sea Research Center, King Abdullah University of Science and Technology (KAUST), Thuwal, Saudi Arabia

3 Institute of Marine Research (IMR), Flødevigen Marine Research Station, 4817 His, Norway

4 Institute of Marine Research (IIM-CSIC), Vigo, Spain

\section{Abstract}

The ballan wrasse, Labrus bergylta (Labridae), is a protogynous hermaphrodite fish common in the north-eastern Atlantic from Norway to Morocco. It is a commercially important resource for local fisheries and is currently being used as cleaner fish to control sea lice in salmon 
farms in northern Europe. Two distinct colour patterns have been recently reported in the literature: plain and spotted. These individuals follow strikingly different life history strategies raising the question of whether they represent one or two independent taxonomic units. Analyses of mitochondrial (18S, COI and control region) and nuclear (S7) markers revealed no genetic differences between these morphotypes. Alternative explanations for the origin and persistence of distinct morphotypes are discussed. AQ1

Responsible Editor: M. Taylor.

Reviewed by Undisclosed experts.

\section{Electronic supplementary material}

The online version of this article (doi:10.1007/s00227-016-2860-8) contains supplementary material, which is available to authorized users.

\section{Introduction}

The ballan wrasse, Labrus bergylta Ascanius, 1767 (Labridae), is a protogynous hermaphrodite fish species common in rocky shores and kelp beds in the north-eastern Atlantic from Norway to Morocco, including the Macaronesian archipelagos of the Canaries, Madeira and Azores (Quignard and Pras 1986; Froese and Pauly 2012). It is a commercially important species to local fisheries in south-western Europe (Treasurer 1994;

Villegas-Ríos et al. 2013a), and it is currently being used as a cleaner fish to control ectoparasites (Copepoda, Caligidae) in salmon farm facilities in northern Europe (Muncaster et al. 2010; Talbot et al. 2012). With the growing importance of the ballan wrasse as a cleaner fish, it became a target of intensive fishing in Norway. Additionally, due to the low abundance of individuals in their natural habitat, intensive culture of this labrid species is currently being developed (Skiftesvik et al. 2013 ). Although salmon farms use preferentially small specimens, the ballan wrasse is the largest labrid in the north-eastern Atlantic (Bañon et al. 2010), which may offer also new opportunities for larger hosts with larger ectoparasites. 
The systematic classification of the Labridae has attracted considerable attention due to the recent split of some taxa and the high intraspecific polymorphism, particularly in the genera Labrus and Symphodus (Almada et al. 2002; Hanel et al. 2002). Recently, Villegas-Ríos et al. (2013a, b) described the existence of two distinct colour patterns in L. bergylta: plain and spotted, with differences in many aspects of their life history strategy including the length-weight relationship, otolith and body growth, size and age structures, timing of sex change, reproductive investment and mortality rates. For example, spotted individuals show larger mean asymptotic sizes, lower mortality rates (Villegas-Ríos et al. 2013a) and lower reproductive investment compared to plain individuals (Villegas-Ríos et al. 2014). Both morphotypes are sympatric along the entire distribution area although the proportion and differentiation between them may change considerably among locations (pers. obs.). No microhabitat segregation or differences in behaviour have been reported so far (Villegas-Ríos 2013). Additionally, unlike most protogynous wrasses (Coulson et al. 2009; Alonso-Fernández et al. 2011), the distinct colour patterns within L. bergylta are not related to sexual dimorphism (Dipper and Pullin 1979; Villegas-Ríos et al. 2013a).

A fundamental question arises from these considerations: are these two morphotypes a single or two independent taxonomic entities? The present study is an attempt to answer this question using multiple genetic markers. This genetic assessment must precede the analysis of the population structure along its entire distribution area, and it is urgent due to its implication over future effects of individual translocations for aquaculture purposes and stock assessment studies.

\section{Materials and methods}

\section{Specimen collection}

A total of 181 samples were collected in four geographic locations throughout the distribution area of the species in the Atlantic north-east: Norway $(n=57)$, North Spain $(n=89)$, Continental Portugal $(n=32)$ and the Azores $(n=3$; Table 1$)$. Samples from Norway were collected with pots by local fishermen. Samples from Portugal (Continental and Azores) and Spain were collected by local fisherman or spear-fished by amateur divers. Individuals were classified as spotted or plain according to the 
criteria described by Villegas-Ríos et al. (2013a). Caudal fin clips were collected, immediately immersed in $96 \%$ ethanol and stored at $4{ }^{\circ} \mathrm{C}$ until use. Voucher tissues were deposited in ISPA (MARE-Marine and Environmental Sciences Centre) collections.

\section{Table 1}

Number of samples, morphotypes and sampling locations of Labrus bergylta, for each DNA marker

\begin{tabular}{|c|c|c|c|c|c|c|}
\hline Morphotype & Region & Coordinates & $\begin{array}{l}\text { Control } \\
\text { region }\end{array}$ & COI & $18 S$ & S7 \\
\hline \multirow{4}{*}{ Plain } & Norway & $58^{\circ} 25^{\prime} \mathrm{N} / 08^{\circ} 45^{\prime} \mathrm{E}$ & 6 & 22 & 22 & 1 \\
\hline & $\begin{array}{l}\text { North } \\
\text { Spain }\end{array}$ & $43^{\circ} 21^{\prime} \mathrm{N} / 08^{\circ} 39^{\prime} \mathrm{W}$ & 14 & 33 & 33 & 8 \\
\hline & $\begin{array}{l}\text { Cont. } \\
\text { Portugal }\end{array}$ & $38^{\circ} 28^{\prime} \mathrm{N} / 08^{\circ} 58^{\prime} \mathrm{W}$ & 22 & 30 & 30 & 18 \\
\hline & Azores & $38^{\circ} 33^{\prime} \mathrm{N} / 28^{\circ} 46^{\prime} \mathrm{W}$ & 1 & 1 & 1 & 1 \\
\hline \multirow{4}{*}{ Spotted } & Norway & $58^{\circ} 25^{\prime} \mathrm{N} / 08^{\circ} 45^{\prime} \mathrm{E}$ & 10 & 19 & 19 & 5 \\
\hline & $\begin{array}{l}\text { North } \\
\text { Spain }\end{array}$ & $43^{\circ} 21^{\prime} \mathrm{N} / 08^{\circ} 39^{\prime} \mathrm{W}$ & 10 & 32 & 32 & 7 \\
\hline & $\begin{array}{l}\text { Cont. } \\
\text { Portugal }\end{array}$ & $38^{\circ} 28^{\prime} \mathrm{N} / 08^{\circ} 58^{\prime} \mathrm{W}$ & 2 & 2 & 2 & 2 \\
\hline & Azores & $38^{\circ} 33^{\prime} \mathrm{N} / 28^{\circ} 46^{\prime} \mathrm{W}$ & 2 & 2 & 2 & 2 \\
\hline
\end{tabular}

\section{DNA extraction, amplification and sequencing}

DNA was extracted with the REDExtract-N-Amp kit (Sigma-Aldrich, www.sigma.com) following the manufacturer's instructions or with proteinase $\mathrm{K}$ and standard phenol-chloroform method (Sambrook and Russell 2001). The quality and concentration of genomic DNA was tested by spectrophotometry using either a NanoDrop Spectrophotometer 2000c (Thermo Scientific, Wilmington, DE, USA) or a Qubit 2.0 Fluorometer dsDNA BR Assay Kit (Life Technologies, Thermo Fisher Scientific, MA), followed by agarose gel electrophoresis.

The following mitochondrial genes were sequenced: control region (CR) and cytochrome oxidase subunit I (COI). Additionally, the small-subunit (18S) ribosomal RNA gene and the first intron of the nuclear S7 ribosomal 
protein gene (S7) were also sequenced. Whenever possible, each specimen was sequenced for the four selected DNA fragments. Primers and PCR conditions are presented in Online Resource 1.

PCR products were purified using MicroClean (Microzone; CR and S7), Illustra ${ }^{\mathrm{TM}}$ ExoStar $^{\mathrm{TM}}$ 1-Step (VWR; COI) and QIAquick Gel Extraction Kit (Qiagen; 18S) following manufacturer instructions. The same primers were used for the sequencing reactions except for the $18 \mathrm{~S}$ which encompassed an internal primer 528F (Elwood et al. 1985) due to the length of the $18 \mathrm{~S}$ fragment (Online Resource 1). Sequencing was performed at STABVIDA (http://www.stabvida.net/) and KAUST BioSciences Core Laboratory (Thuwal, Saudi Arabia). Sequences were edited with Codon Code Aligner (Codon Code Corporation) and aligned with Clustal X 2.1 (Larkin et al. 2007).

\section{$\mathrm{AQ} 3$}

\section{DNA analysis}

ARLEQUIN software package V.3.5 (Excoffier and Lischer 2010) was used to estimate the genetic diversity and to compute pairwise FSTs. In the case of the S7 the analyses were also run in ARLEQUIN, after allowing the programme to reconstruct the genotypes present, using the ELB algorithm. Haplotype networks were built with the software TCS 1.21 (Clement et al. 2000 ) using the parsimony method of Templeton et al. (1992).

\section{Results}

Sequences have been deposited in the GenBank database under the following Accession numbers: KU306119-KU306185 (CR), [Accession numbers] (COI), [Accession numbers] (18S), KU306186-KU306230 (S7).

The 18S sequences with 1828 base pairs (bp) were identical for all the individuals analysed independently of the morphotype considered or its geographical origin.

The analysis of the COI sequences with $710 \mathrm{bp}$ has revealed a single DNA polymorphism (SNP). This SNP did not reflect any divergence between morphotypes since both plain and spotted individuals presented the two alternative nucleotides.

The CR, with a total of 333 bp yielded 51 polymorphic sites, revealed 39 
different haplotypes with six of them being shared by plain and spotted individuals. In general, diversity indices were high for both morphotypes (Table 2$)$. No differences in pairwise FSTs $\left(F_{\text {st }}=0.02 ; P=0.14\right)$ were found between morphotypes.

\section{Table 2}

Haplotype numbers and diversity indices for Labrus bergylta's CR and S7

\begin{tabular}{|c|c|c|c|c|c|c|c|}
\hline & \multicolumn{5}{|c|}{ CR } & \multicolumn{2}{|l|}{ S7 } \\
\hline & $N$ & NH & $\begin{array}{l}\text { Haplotype } \\
\text { diversity } \pm \text { SD }\end{array}$ & $\begin{array}{l}\text { Nucleotide } \\
\text { diversity } \pm \text { SD }\end{array}$ & $\begin{array}{l}\text { Mean number } \\
\text { of pairwise } \\
\text { differences }\end{array}$ & $N$ & \\
\hline Plain & 43 & 28 & $0.973 \pm 0.011$ & $0.028 \pm 0.014$ & $9.161 \pm 4.297$ & 58 & 17 \\
\hline Spotted & 24 & 16 & $0.935 \pm 0.039$ & $0.037 \pm 0.019$ & $12.243 \pm 5.731$ & 32 & 19 \\
\hline
\end{tabular}

$N$ number of individuals, $N H$ number of haplotypes (in S7, as calculated by ARLE ELB algorithm), $S D$ standard deviation

The S7, with 534 bp yielded 12 polymorphic sites, was unable to discriminate between morphotypes either analysing pairwise FST's $\left(F_{\text {st }}=0.005 ; P=0.34\right)$ or considering each single polymorphism. Additionally, from the 22 haplotypes identified six were shared between plain and spotted individuals along the entire sampled area.

The CR and S7 haplotype networks (Fig. 1 a, b) fully support these results, with several haplotypes being shared by both morphotypes along the entire distribution area of this species, including remote locations such as the Archipelago of the Azores.

\section{Fig. 1}

a Haplotype networks for the CR and b S7 gene for L. bergylta. The ancestral haplotype estimated by TCS is identified by a square. Circle area is proportional to each haplotype frequency and each circle depicts the geographical origin of samples. The number of samples from plain and spotted colour patterns is represented by green (with a dot) and red (with a cross) boxes, respectively. Notches represent base pair differences between haplotypes 


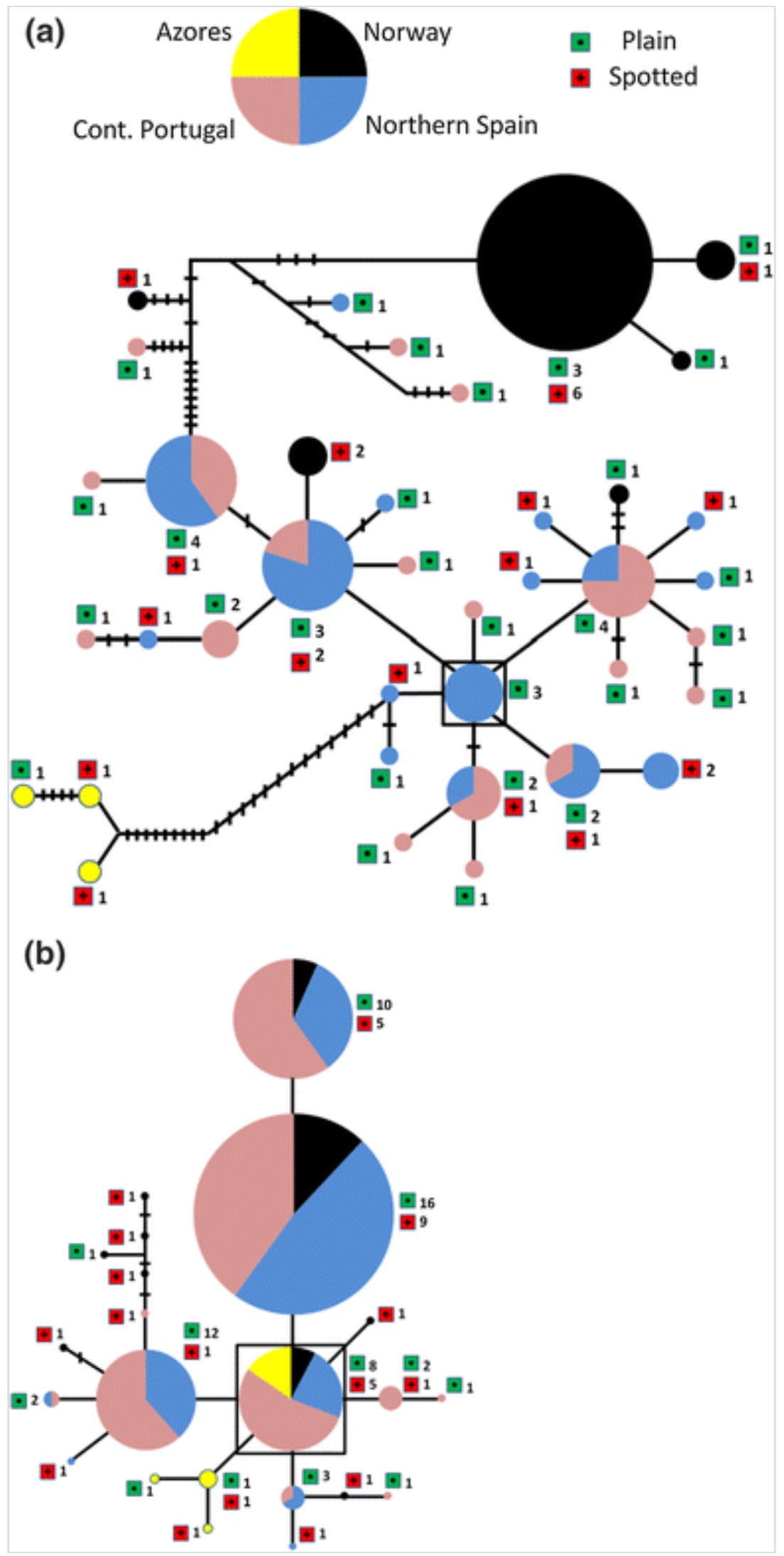

\section{Discussion}

The four mitochondrial and nuclear DNA fragments analysed in this study revealed no genetic differences between $L$. bergylta's plain and spotted morphotypes, with shared haplotypes (15\% CR; $100 \%$ COI; $100 \% 18 \mathrm{~S}$ and $27 \%$ S7 first intron) along the entire sampling area. These markers 
provide genetic information suitable for identifying cryptic species and very recent divergence events, especially $\mathrm{CR}$ data, which has been extensively used to detect phylogeographic structure in fish, including labrid species (e.g. Robalo et al. 2012; D’Arcy et al. 2013). Additionally, the combination $\mathrm{CR}+\mathrm{S} 7$ has been used in several phylogeographic studies of north-eastern Atlantic fish species belonging to several families from different lineages (e.g. Blenniidae, Domingues et al. 2007a; Francisco et al. 2011; Sparidae, Domingues et al. 2007b; Cottidae, Almada et al. 2012). Nevertheless, we are aware that our sample coverage is not equivalent for the analysed markers; therefore, these results should be interpreted with caution.

AQ4

The existence of two distinct phenotypic forms throughout the distribution area of the species can be explained by different hypotheses. First, it could be the result of a divergent evolutionary process between sympatric populations of $L$. bergylta driven by assortative mating (prezygotic isolation) of the species. The combination of assortative mating and disruptive natural selection on a single trait, the so-called magic trait (Gavrilets 2004), can initiate speciation in marine environments, even in the absence of geographic barriers and high gene flow (Puebla et al. 2007; Barreto and McCartney 2008; Choat et al. 2012). Although the role of colour variation in speciation processes has not been well established yet, the potential for this phenotypic trait to drive diversification was demonstrated via assortative mating in marine and freshwater fish species (Puebla et al. 2007; Elmer et al. 2009; Puebla 2009). Second, it could also be due to a very recent allopatric divergence followed by a complete recolonization of the north-eastern Atlantic by both phenotypic forms. However, our results showing shared haplotypes in very distinct regions do not support cryptic speciation or recent divergence between both morphotypes. In fact our results suggest a geographic rather than a phenotypic signature with identical or similar haplotypes in different regions independently of their phenotypic form. Additional hypotheses to explain the differences between morphotypes include epigenetic regulation and environmental effects. In fact, phenotype evolution in fish, namely body colour pattern, may result from an epigenetic process associated with gene expression regulation (see Maan and Sefc 2013 for a review). On the other hand, different habitat and diet preferences are frequently related with differences in body colour patterns in fish (Sherwood and Grabowski 
2010; Sefc et al. 2014). In the case of L. bergylta, although ad libitum scuba-diving observations point to some degree of segregation between breeding adults from both morphotypes, no microhabitat differences have been reported so far (Villegas-Ríos et al. 2013a and pers. obs.), and a comparative analysis of the diet of both morphotypes remains to be performed.

From a management perspective, fisheries preferentially target the largest and most valuable specimens. This implies that spotted individuals may be under stronger selective pressure because: (1) they attain larger mean sizes and larger market values since they are commercialized as a different species by local fisheries (Villegas-Ríos et al. 2013a and pers. obs.); (2) their larger sizes-at-age are attained at the cost of their lower reproductive output (Villegas-Ríos et al. 2013b); (3) unbalanced sex ratios due to malebiased overexploitation may occur since the ballan wrasse is a protogynous hermaphrodite fish. If this is true along the entire distribution area, and considering that this species is now being used as cleaner in salmon aquaculture, conditions are created to observe a rapid decline of the spotted compared to the plain morphotype, especially if the origin of these morphological differences remains unknown. Although there is still no information available supporting the genetic singularity of the morphotypes, we suggest that, as a precautionary measure, plain and spotted should be considered two independent management units.

Further studies are needed to address the life history differences between plain and spotted morphotypes. A set of 20 microsatellite loci was recently described for this species by Quintela et al. (2014) which will also allow for a detailed study of gene flow and recent population differentiation. Alternative markers, such as SNPs, could also give a more detailed picture if both neutral and non-neutral markers are considered. The results presented here point to the importance of expanding D'Arcy et al. (2013) phylogeographic analysis to the entire distribution area of this species to clarify the genetic distinctiveness of some remote locations (e.g. Azores). Although our results reveal no genetic isolation between both morphotypes, there is a suggestion that some degree of geographical structure may emerge when additional samples from more geographical areas are analysed in the future. 


\section{Acknowledgments}

We thank the help of Patricia Carvalho during field work at Madeira and Sérgio Bexiga, Catarina Craveiro, Filipe Tadeu, Ana Patrícia Rafael, Catarina Chaves and Inês Castanheira with DNA sequencing. This study was funded by the Eco-Ethology Research Unit' Strategic Plan (PEstOE/MAR/UI0331/2011)—Fundação para a Ciência e a Tecnologia—FCT (partially FEDER funded). F.A. (SFRH/BPD/63170/2009) and S.M.F. (SFRH/BPD/84923/2012) were supported by FCT grants. D.V.R. was supported by a Marie Curie Intra European Fellowship within the 7th European Community Framework Programme (Grant No. 625852).

\section{Electronic supplementary material}

Below is the link to the electronic supplementary material.

\section{Online Resource 1}

Primers and polymerase chain reaction conditions used for Labrus bergylta (PDF $363 \mathrm{~kb}$ )

\section{References}

Almada VC, Almada F, Henriques M, Santos RS, Brito A (2002) On the phylogenetic affinities of Centrolabrus trutta and Centrolabrus caeruleus (Perciforms: Labridae). Molecular and meristic evidence. Arquipel Life Mar Sci 19:85-92

Almada VC, Almada F, Francisco SM, Castilho R, Robalo JI (2012) Unexpected high genetic diversity at the extreme Northern geographic limit of Taurulus bubalis (Euphrasen, 1786). PLoS One 7:e44404. doi:10.1371/journal.pone.0044404

Alonso-Fernández A, Alós J, Grau A, Domínguez-Petit R, Saborido Rey F (2011) The use of histological techniques to study the reproductive biology of the hermaphroditic mediterranean fishes Coris julis, Serranus scriba and Diplodus annularis. Mar Coast Fish 3:145-159. doi:10.1080/19425120.2011.556927

Bañon R, Villegas-Ríos D, Serrano A, Mucientes G, Arronte JC (2010) 
Marine fishes from Galicia (NW Spain): an updated checklist. Zootaxa 2667:1-27

Barreto FS, McCartney MA (2008) Extraordinary AFLP fingerprint similarity despite strong assortative mating between reef fish color morphospecies. Evolution 62:1-8. doi:10.1111/j.15585646.2007.00285.x

Choat JH, Klanten OS, Van Herwerden L, Robertson DR, Clements KD (2012) Patterns and processes in the evolutionary history of parrotfishes (Family Labridae). Biol J Linn Soc 107:529-557

Chow S, Hazama K (1998) Universal PCR primers for S7 ribosomal protein genes in fish. Mol Ecol 7:1255-1256. doi:10.1046/j.1365294x.1998.00406.x

Clement M, Posada D, Crandall KA (2000) TCS: a computer program to estimate gene genealogies. Mol Ecol 9:1657-1660. doi:10.1046/j.1365-294x.2000.01020.x

Coulson PG, Hesp SA, Hall NG, Potter IC (2009) The western blue groper (Achoerodus gouldii), a protogynous hermaphroditic labrid with exceptional longevity, late maturity, slow growth, and both late maturation and sex change. Fish Bull 107:57-75

D’Arcy J, Mirimin L, FitzGerald R (2013) Phylogeographic structure of a protogynous hermaphrodite species, the ballan wrasse Labrus bergylta, in Ireland, Scotland, and Norway, using mitochondrial DNA sequence data. ICES J Mar Sci. doi:10.1093/icesjms/fst018 AQ6

Dipper FA, Pullin RSV (1979) Gonochorism and sex-inversion in British Labridae (Pisces). J Zool 187:97-112. doi:10.1111/j.14697998.1979.tb07716.x

Domingues VS, Faria C, Stefanni S, Santos RS, Brito A, Almada VC (2007a) Genetic divergence in the Atlantic-Mediterranean Montagu's blenny, Coryphoblennius galerita (Linnaeus 1758) revealed by molecular and morphological characters. Mol Ecol 16:3592-3605. 
doi:10.1111/j.1365-294X.2007.03405.X

Domingues VS, Santos RS, Brito A, Alexandrou M, Almada VC (2007b) Mitochondrial and nuclear markers reveal isolation by distance and effects of Pleistocene glaciations in the northeastern Atlantic and Mediterranean populations of the white seabream (Diplodus sargus, L.). J Exp Mar Biol Ecol 346:102-113. doi:10.1016/j.jembe.2007.03.002

Elmer KR, Lehtonen TK, Meyer A (2009) Color assortative mating contributes to sympatric divergence of neotropical cichlid fish. Evolution 63:2750-2757. doi:10.1111/j.1558-5646.2009.00736.x

Elwood HJ, Olsen GJ, Sogin ML (1985) The small-subunit ribosomal RNA gene sequences from the hypotrichous ciliates Oxytricha nova and Stylonychia pustulata. Mol Biol Evol 2:399-410

Excoffier L, Lischer H (2010) Arlequin suite ver 3.5: a new series of programs to perform population genetics analyses under Linux and Windows. Mol Ecol Resour 10:564-567. doi:10.1111/j.17550998.2010.02847.x

Folmer O, Black M, Hoeh W, Lutz R, Vrijenhoek R (1994) DNA primers for amplification of mitochondrial cytochrome $c$ oxidase subunit I from diverse metazoan invertebrates. Mol Mar Biol Biotechnol 3:294-299

Francisco SM, Faria C, Lengkeek W, Vieira MN, Velasco EM, Almada VC (2011) Phylogeography of the shanny Lipophrys pholis (Pisces: Blenniidae) in the NE Atlantic records signs of major expansion event older than the last glaciation. J Exp Mar Biol Ecol 403:14-20. doi:10.1016/j.jembe.2011.03.020

Froese R, Pauly D (2012). FishBase World Wide Web electronic publication. www.fishbase.org. Accessed 15 Apr 2015

Gavrilets S (2004) Fitness landscapes and the origin of species (MPB41). Princeton University Press, Princeton

Hanel R, Westneat MW, Sturmbauer C (2002) Phylogenetic 
relationships, evolution of broodcare behavior, and geographic speciation in the wrasse tribe Labrini. J Mol Evol 55:776-789. doi:10.1007/s00239-002-2373-6

Larkin MA, Blackshields G, Brown NP, Chenna R, McGettigan PA, McWilliam H, Valentin F, Wallace IM, Wilm A, Lopez R, Thompson JD, Gibson TJ, Higgins DG (2007) Clustal W and Clustal X version 2.0. Bioinformatics 23:2947-2948. doi:10.1093/bioinformatics/btm404

Maan ME, Sefc KM (2013) Colour variation in cichlid fish: developmental mechanisms, selective pressures and evolutionary consequences. Sem Cell Dev Biol 24:516-528.

doi:10.1016/j.semcdb.2013.05.003

Moon-van der Staay SY, Van Der Staay GWM, Guillou L, Claustre H, Medlin LH, Vaulot D (2000) Abundance and diversity of Prymnesiophyceae in the picoplankton community from the equatorial Pacific Ocean inferred from 18S rDNA sequences. Limnol Oceanogr 45:98-109. doi:10.4319/1o.2000.45.1.0098

Muncaster S, Andersson E, Kjesbu OS, Taranger GL, Skiftesvik AB, Norberg B (2010) The reproductive cycle of female Ballan wrasse Labrus bergylta in high latitude, temperate waters. J Fish Biol 77:494511. doi:10.1111/j.1095-8649.2010.02691.x

Ostellari L, Bargelloni L, Penzo E, Patarnello P, Patarnello T (1996) Optimization of single-strand conformation polymorphism and sequence analysis of the mitochondrial control region in Pagellus bogaraveo (Sparidae, Teleostei): rationalized tools in fish population biology. Anim Genet 27:423-427. doi:10.1111/j.13652052.1996.tb00510.x

Puebla O (2009) Ecological speciation in marine v. freshwater fishes. J Fish Biol 75:960-996. doi:10.1111/j.1095-8649.2009.02358.x

Puebla O, Bermingham E, Guichard F, Whiteman E (2007) Colour pattern as a single trait driving speciation in Hypoplectrus coral reef fishes? Proc R Soc Lond Biol 274:1265-1271.

doi:10.1098/rspb.2006.0435 
Quignard JP, Pras A (1986) Labridae. In: Whitehead PJP, Bauchot M-L, Hureau J-C, Nielsen J, Tortonese E (eds) The fishes of the Northeastern Atlantic and the Mediterranean II. UNESCO, Paris

Quintela M, Danielsen EA, Svåsand T, Knutsen H, Skiftesvik AB, Glover KA (2014) Isolation and characterization of twenty microsatellite loci for the ballan wrasse, Labrus bergylta. Conserv Genet Resour 6:425-428. doi:10.1007/s12686-013-0114-3

Robalo JI, Castilho R, Francisco SM, Almada F, Knutsen H, Jorde PE, Pereira AM, Almada VC (2012) Northern refugia and recent expansion in the North Sea: the case of the wrasse Symphodus melops (Linnaeus, 1758). Ecol Evol 2:153-164. doi:10.1002/ece3.77

Sambrook J, Russell D (2001) Molecular cloning: a laboratory manual. Cold Spring Harbor Laboratory Press, Cold Spring Harbor

Sefc KM, Brown AC, Clotfelter ED (2014) Carotenoid-based coloration in cichlid fishes. Comp Biochem Physiol A 173:42-51.

doi:10.1016/j.cbpa.2014.03.006

Sherwood GD, Grabowski JH (2010) Exploring the life-history implications of colour variation in offshore Gulf of Maine cod (Gadus morhua). ICES J Mar Sci 67:1640-1649. doi:10.1093/icesjms/fsq094

Skiftesvik AB, Bjelland RM, Durif CM, Johansen IS, Browman HI (2013) Delousing of Atlantic salmon (Salmo salar) by cultured vs. wild ballan wrasse (Labrus bergylta). Aquaculture 402:113-118.

doi:10.1016/j.aquaculture.2013.03.032

Talbot C, Medeiros MV, Davie A (2012) In vivo gender determination in captive ballan wrasse (Labrus bergylta Ascanius 1767). Final report to the Scottish Salmon Producers Organisation 54

Templeton AR, Crandall KA, Sing CF (1992) A cladistic analysis of phenotypic associations with haplotypes inferred from restriction endonuclease mapping and DNA sequence data. III. Cladogram estimation. Genetics 132:619-633 
Treasurer J (1994) Prey selection and daily food consumption by a cleaner fish, Ctenolabrus rupestris (L.), on farmed Atlantic salmon, Salmo salar L. Aquaculture 122:269-277. doi:10.1016/00448486(94)90337-9

Villegas-Ríos D (2013) Life-history and behaviour of Labrus bergylta in Galicia. PhD thesis, University of Vigo, Spain

Villegas-Ríos D, Alonso-Fernández A, Domínguez-Petit R, SaboridoRey F (2013a) Intraspecific variability in reproductive patterns in the temperate hermaphrodite Labrus bergylta. Mar Freshw Res 64:11561168. doi:10.1071/MF12362

Villegas-Ríos D, Alonso-Fernández A, Fabeiro M, Bañón R, SaboridoRey F (2013b) Demographic variation between colour patterns in a temperate protogynous hermaphrodite, the ballan wrasse Labrus bergylta. PLoS One 8(8):e71591. doi:10.1371/journal.pone.0071591

Villegas-Ríos D, Alonso-Fernández A, Domínguez-Petit R, SaboridoRey F (2014) Energy allocation and reproductive investment in a temperate protogynous hermaphrodite, the ballan wrasse Labrus bergylta. J Sea Res 86:76-85. doi:10.1016/j.seares.2013.11.010 